\title{
Desain furnitur hasil kajian seting fisik kelas studio berbasis perilaku mahasiswa milenial
}

\author{
Dwi Sulistyawati, ${ }^{1 *}$ Imam Santosa, $^{2}$ Deddy Wahyudi ${ }^{2}$ \\ ${ }^{1}$ Program Studi Desain Interior, Fakultas Seni Rupa dan Desain, Universitas Tarumanegara, Jakarta, Indonesia \\ ${ }^{2}$ Program Doktor Ilmu Seni Rupa dan Desain, Institut Teknologi Bandung, Indonesia
}

\begin{abstract}
Activities and behavior Millennials have special characteristics, as a result of being influenced by information technology tools that bring about changes in various aspects that can have an impact on the problem. The starting point of the problem that must be solved is that the behavior of Millennial students behaves in terms of the learning process in accordance with the applicable curriculum to get the right means of space (physical arrangement) so that it is expected to contribute to the effectiveness in achieving the target of the learning process, which refers to research on activities users, especially the activities of millennial generation lecturers and students in behaving in class. Physical Setings Products that can show the relationship between spatial conditions, needs and behavior of millennial students in class. The results of this study then become the basis for creating a classroom arrangement model that is tailored to the curriculum and characteristics of millennial students.
\end{abstract}

Key words: activity behavior, millennial students, physical setings, products

\begin{abstract}
Abstrak
Aktivitas dan perilaku generasi milenial memiliki karakteristik khusus, akibat dipengaruhi oleh perangkat teknologi informasi yang membawa perubahan dalam berbagai aspek yang memungkinkan bisa membawa dampak masalah. Titik awal dari masalah yang harus dipecahkan adalah bahwa perilaku siswa milenium berperilaku dalam hal proses pembelajaran harus dapat disesuaikan sesuai dengan kurikulum yang berlaku untuk mendapatkan sarana dan prasarana ruang yang tepat (pengaturan fisik dan produk yang dihasilkan) sehingga diharapkan dapat berkontribusi pada efektivitas dalam mencapai target proses pembelajaran, yang mengacu pada penelitian tentang aktivitas pengguna, terutama kegiatan dosen dan mahasiswa generasi milenial dalam berperilaku di kelas. Produk Seting Fisik yang dapat menunjukkan hubungan antara kondisi spasial, kebutuhan dan perilaku siswa milenial dalam kelas. Hasil penelitian ini kemudian menjadi dasar untuk membuat model pengaturan ruang kelas yang disesuaikan dengan kurikulum dan karakteristik mahasiswa milenial.
\end{abstract}

Kata kunci: mahasiswa milenial, perilaku aktivitas, produk, seting fisik

\section{Pendahuluan}

Banyak hal yang perlu diperhatikan dalam menjalankan aktivitas di bidang pendidikan seni dan desain, terutama dalam kegiatan belajar mengajar. Keberhasilan kegiatan ini tergantung pada cara mengajar yang didukung oleh fasilitas dan infrastruktur dengan menyesuaikan perilaku mahasiswa generasi milenial. Setiap generasi mempunyai karakteristik umum yang akan menjadi karakter generasi itu dengan empat pola yang berulang. Tidak terkecuali generasi milenial. Strauss dan Howe menjelaskan ada beberapa karakter Milenial yaitu: spesial, terlindungi, percaya diri, dan berwawasan kelompok (Strauss \& Howe, 2000). Sebagai ilustrasi, generasi milenial dari kelas menengah urban adalah generasi yang memiliki karakteristik khas, yaitu 3C, yang berasal dari Creative, Confidence, dan Connected (Ali \& Purwandi, 2017). Generasi pertama milenial kelas menengah perkotaan adalah generasi kreatif. Mereka terbiasa berpikir Out of the Box, kaya akan ide. Generasi kedua Millennial urban middle class adalah generasi Confidence. Mereka sangat percaya diri dan

\footnotetext{
* Corresponding author Tel : +62 816-960-254 ; e-mail : soeli1988@gmail.com
} 
berani mengungkapkan pendapat mereka tanpa raguragu. Ketiga, generasi milenial dari kelas menengah perkotaan adalah generasi Connected. Mereka selalu terhubung satu dengan yang lainnya setiap saat. Aktivitas dan perilaku mereka tersebut dipengaruhi oleh perangkat teknologi informasi (Zuhal, 2000). Tidak saja dengan teknologi informasi, mereka juga sangat memahami keterkaitan komunikasi di antara mereka dengan wadah seting fisiknya.

Salah satu sarana atau wadah aktivitas mahasiswa milenial berperilaku adalah ruang kelas. Perancangan ruang kelas memerlukan pengamatan dan pemahaman untuk mengetahui kebutuhan dari beberapa aktivitas pembelajaran seni dan desain, agar pelaku kegiatan di dalamnya mendapatkan kenyamanan dan kesesuaian antara perilaku dan seting fisiknya, hingga proses belajar berjalan sesuai dengan target yang ditentukan.

Pengamatan terhadap perilaku mahasiswa milenial adalah bentuk pencarian ruang kelas yang sesuai dengan aktivitas berperilakunya yang dapat memberikan perubahan pada seting fisiknya. Perubahan tentu saja dapat dilakukan dengan berbagai cara misalnya menambah jumlah kapasitas dan penjadwalan pemakaian ruang dengan perbedaan waktu bagi tiap kelompok dengan kegiatan yang terpola, memodifikasi perabotan, atau penggantian tata letak ruang.

Perubahan dalam karakter pola perilaku mahasiswa milenial pada seting fisiknya dapat disebabkan oleh perubahan fisik, sosial, dan struktur administrasi sistem pembelajaran yang terdapat pada seting tersebut. Asumsi ini merupakan hal yang sangat penting khususnya untuk merencanakan perubahan lingkungan yang condong kepada suatu pemaksaan. Keruwetan yang terjadi dalam suatu ruang dapat dikurangi dengan membangun ruang lainnya atau dengan mengurangi jumlah pemakai. Sejumlah batasan harus diberikan untuk menentukan metode apa saja yang layak pakai dan sesuai dengan masalahnya.

Demikian pula halnya aktivitas mahasiswa milenial berperilaku dan bergerak dalam ruang kelas dapat membentuk seting fisik, dalam hal ini seting fisik tersebut dapat mempengaruhi efektifitas dalam proses belajar mahasiswa, tentunya terkait dengan sistem pembelajaran di dalam ruang kelas tersebut. Secara tidak langsung penelitian ini dapat memberi manfaat bagi pengguna ruang kelas dalam melakukan kegiatan belajar dan mengajar yang lebih efektif. Masalahnya adalah bagaimana mendeskripsikan hasil yang telah didapat dari pengamatan aktivitas mahasiswa dan dosen dalam berperilaku di dalam ruang kelas mata kuliah perancangan dan seni pada kelas seni dan desain pada sekolah dalam bentuk model, dan bagaimana memvisualisasikan ke dalam model seting fisik setelah didapatkan hasil data fisik, latar belakang pengguna, aktivitas dalam kelas, serta fenomena yang sudah terjadi dalam kelas.

Tahapannya adalah mengamati mahasiswa milenial berperilaku yang terjadi di dalam ruang kelas terhadap seting fisik ruang kelas pada sekolah seni dan desain dan mendeskripsikan hasil yang telah didapat dari pengamatan aktivitas mahasiswa dalam berperilaku di dalam ruang kelas tersebut dalam bentuk model behavior setting, sebagai pedoman di dalam menentukan model physical setting, kemudian membuat model seting fisik ruang kelas seni dan desain berdasarkan pedoman yang telah ditentukan.

Hasil analisis dan model seting fisik dapat menjadikan masukan bagi bidang pendidikan tentang pertimbangan pengadaan fasilitas ruang ajar, khususnya pada pendidikan seni dan desain, yang dapat memberikan sumbangan keilmuan bagi lembaga pendidikan bidang seni dan desain terhadap perilaku siswa milenial.

\section{Bahan dan metode}

Data dalam penelitian ini terbagi menjadi dua jenis, yaitu data primer dan data sekunder (Creswell, 2014). Data primer merupakan data yang akan diperoleh melalui pengamatan langsung pada beberapa ruang kuliah, observasi/pengukuran ruang kelas dan pengamatan sewaktu dengan teknik perekaman gambar dan video pada saat pelajaran mata kuliah tersebut berlangsung. Sedangkan data sekunder adalah data yang didapat dari berbagai referensi atau pustaka yang mendukung. Penelitian di tahap pertama menggunakan teknik perekaman data berupa gambar layout/Tampak atas, foto dan video saat perkuliahan sedang berjalan dari awal hingga akhir di dalam kelas. Perekaman data tersebut haruslah tanpa disadari oleh pengguna ruang sehingga data yang diperoleh tidak bias dan dapat lebih natural. Pengukuran pada ruang kelas studio kemungkinan adanya perubahan layout furnitur dalam ruang (evaluasi aktivitas mahasiswa, dosen dan asisten dosen), yaitu: (1) Mengukur dan menggambar ruang kelas studio sebagai obyek kasus. (2) Pengambilan rekam aktivitas pengguna dalam berperilaku berdasarkan Silabus, Kurikulum, SAP pada obyek beberapa ruang kelas pada mata kuliah studio. (3) Memberikan kuesioner dan wawancara tak terstruktur untuk siswa milenial. 
Mendeskripsikan hasil yang telah didapat dari pengamatan aktivitas siswa milenial dalam berperilaku didalam ruang kelas studio dalam bentuk model seting perilaku, sebagai pedoman didalam menentukan model seting fisik. (5) Membuat skematik dan konsep desain dari hasil analisa dan penyimpulan data pada kelas studio seni dan desain (Gambar 1). (6) Membuat model seting fisik ruang pada kelas studio seni dan desain berdasarkan pedoman yang telah ditentukan.

Metoda yang digunakan untuk mendapatkan seting fisik adalah menggunakan metode Programing Konsep berdasarkan temuan di lapangan tentang beberapa masalah pengguna mahasiswa milenial dengan kegiatan dan perilakunya di dalam kelas studio (Gambar 2).

\section{SKEMATIK DESAIN}

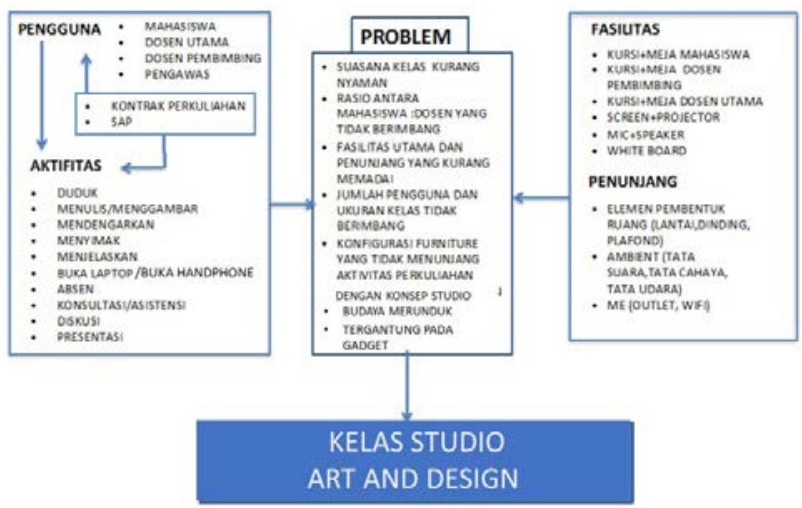

Gambar 1. Bagan programing skematik desain

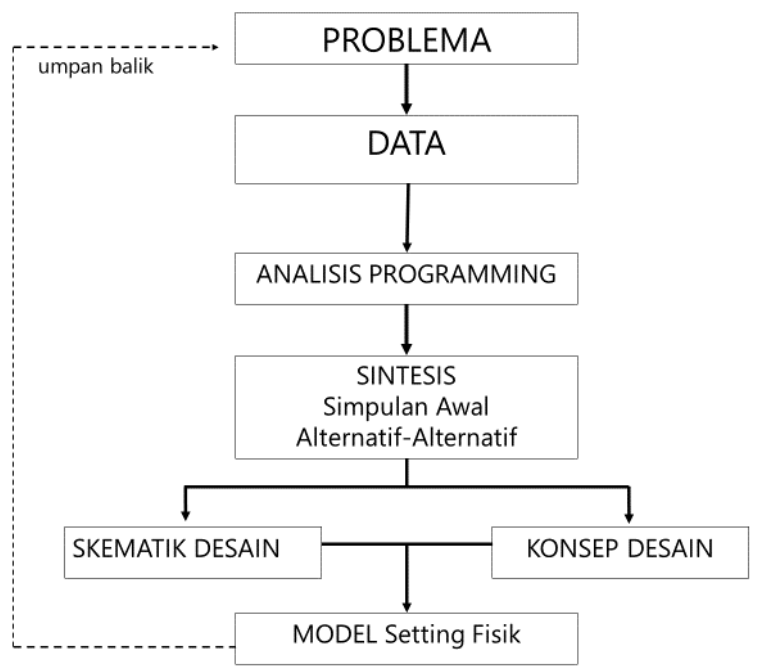

Gambar 2. Bagan programing konsep

\section{Hasil dan pembahasan}

Kelas adalah merupakan wadah dari masyarakat kecil sebagai bagian dari masyarakat sekolah, yang diorganisir menjadi unit kerja yang secara dinamis dalam menyelenggarakan kegiatan pembelajaran yang kreatif untuk mencapai suatu tujuan. Kelas, tidak sekedar hanya kelas yang merupakan ruangan yang dibatasi dinding tempat para siswa berkumpul bersama untuk mempelajari segala yang disajikan oleh pengajar, tetapi lebih dari itu kelas merupakan suatu unit kecil mahasiswa yang berinteraksi dengan dosen dalam proses pembelajaran dengan beragam keunikan yang dimiliki (Azwar, 2007).

\section{Ruang kelas sebagai sistem interaksi}

Hubungan antara dosen dan mahasiswa di ruang kelas merupakan sebuah interaksi sosial, di mana konsep persahabatan dan pemuridan terjadi dalam hubungan yang timbal balik, di mana terjalin suatu kontak dan komunikasi yang bersifat teratur dan terstruktur. Hubungan kedua pihak ini berkaitan dengan moral dan etika profesi kependidikan, dimana masing-masing sebelumnya sudah memiliki motif, keinginan, kepentingan, kebutuhan dan orientasi tersendiri berkaitan dengan kependidikan. Pada fase awal terjadi penjajakan pembentukan pola, yang berkaitan dengan persepsi, sikap dan tindakan tentang eksistensi masing-masing. Fase lanjutannya, terbentuk pola hubungan dimana adanya persepsi, sikap dan tindakan bersama dan menjadi rujukan dalam berperilaku, seperti disiplin, kerapian, pekerjaan rumah, ujian dan lain sebagainya. Dalam interaksi di ruang kelas diharapkan masing-masing individu dapat membentuk situasi, interpretasi realitas dan pemaknaan kenyataan yang dihadapinya, dalam kerangka pembentukan kepribadian individu.

\section{Ruang kelas sebagai sistem pertukaran}

Hubungan antara dosen dan mahasiswa di kelas merupakan sebuah sistem pertukaran, dalam rangka memperoleh keuntungan, baik yang bersifat ekstrinsik berupa materi dan kebendaan, maupun intristik berupa nilai (peringkat), penghargaan, pengakuan, cinta kasih dari para murid, orang tua dan unsur lainnya. Dalam hal ini, hubungan pertukaran ini dilakukan untuk memperoleh proposisi sukses (yakni mempertimbangkan perolehan ganjaran/hadiah, sehingga cenderung mengulangi perbuatannya), proposisi stimulus (berkaitan dengan tindakan spekulasi sebagai kemungkinan untuk mendapatkan hadiah/ganjaran seperti pada masa lalu), proposisi nilai (pilihan terhadap sesuatu yang lebih bernilai dibandingkan dengan yang lainnya), proposisi deprivasi-satiasi (berkaitan dengan tingkat 
kejenuhan dan kemungkinan memperoleh nilai), proposisi agregasi-persetujuan (berkaitan dengan ganjaran/hadiah yang tidak sesuai menurut yang diharapkan) dan proposisi rasionalitas (berkaitan dengan pilihan rasional yang berkaitan dengan kemungkinan yang paling rasional).

Pendekatan Interaksi (memberikan perhatian pada metode pengajaran dalam mengelola ruang kelas yang efisien), berkaitan dengan beberapa hal, terdapat beberapa pendekatan sosiologi terhadap ruang kelas yakni: (1) Perilaku dominatif versus Integratif; (2) Gaya Kepemimpinan Guru; (3) Teacher Centered versus Learner Centered; (4) Ruang Kelas, Pemeliharaan Ketertiban, dan Kedisiplinan (Damsar, 2011).

Perilaku dominatif versus Integratif. Perilaku dominatif berkaitan dengan posisi guru sebagai sumber kebenaran, yang dipandang maha tahu, tokoh penentu benar salah, dalam hal ini siswa dianggap sebagai mahluk yang senantiasa harus dibimbing dan diarahkan oleh guru. Sebaliknya perilaku integratif berkaitan dengan posisi guru sebagai sumber motivasi dan inspirasi bagi peserta didik, tidak diskriminatif apapun latar belakang perserta didik, dalam hal ini siswa didorong untuk mencari sendiri pengetahuan dan kebenarannya.

Gaya Kepemimpinan Guru dapat mempengaruhi produktifitas siswa di ruang kelas, yang dibedakan menjadi autokratik (kepemimpinan yang otoriter yang tidak memberikan ruang bertukar pendapat atau pandangan antara guru-murid), demokratik (adanya ruang untuk bertukar pandangan atau pendapat dan kebaikan bersama dikonstruksikan secara bersama melalui musyawarah) dan laisser-faire (kepemimpinan yang cuek dimana peserta didik diperbolehkan melakukan apa saja apabila dipandang penting untuk dilakukan). Gaya demokratis bagi siswa milenial diharapkan merupakan gaya yang diharapkan karena memberikan ruang gerak bagi kreativitas bersama yang membentuk sosialbudaya yang solider dan saling menghargai (Murray, 1985).

Teacher Centered versus Learner Centered. Dalam hal ini, proses belajar mengajar itu berpusat pada guru atau perpusat pada pelajar. Berpusat pada guru akan membentuk ketergantungan siswa pada guru, sementara berpusat pada siswa akan membentuk kemandirian pada murid. Jadi pendekatan berpusat pada siswa lebih efektif bagi siswa generasi milenial yang sudah dipengaruhi oleh teknologi informasi. (1) Pendekatan Interpretatif: Interpretasi dipahami sebagai proses mendefinisikan situasi, dengan proses penilaian dan pertimbangan melalui pemberian makna terhadap stimulus yang diterimanya. Dalam istilah W.I. Thomas: "Jika seseorang mendefinisikan sesuatu itu sebagai nyata, situasi itu nyata dalam konsekuensinya”; misalnya jika siswa disituasikan bodoh, maka situasi itu nyata dalam konsekuensi metode pembelajaran guru yang outokratik (Lovitt, 1984). Dalam pemahaman ini, sebenarnya sekolah dapat dikatakan sebagai alat untuk melakukan penanaman defenisi situasi dan melakukan kontrol sosial. (2) Pendekatan Radikal /labelling: Pendekatan ini dikatakan radikal karena ia selalu mempertanyakan tentang "apa memang seharusnya demikian?” dan memberikan alternatif cara pandang terhadap sesuatu. Pendekatan ini melakukan analisa kritis terhadap teori labelling, yang memandang bahwa label merupakan bagian dari konsep diri, yang membawa seseorang ke arah persepsi, prasangka atau penyimpangan tertentu seperti yang dikenakan padanya. Dampak pemberian label pada siswa ialah self-fulfilling (pembenaran ramalan pribadi), yakni pembenaran terhadap label dengan menegaskan persepsi dan praduga tentang diri mereka sebagaimana orang lain memandang mereka (Azwar, 2007).

Ruang Kelas, Pemeliharaan Ketertiban dan Kedisiplinan. Pemeliharaan ketertiban dan disiplin memiliki keterkaitan yang sangat erat, yang berkaitan dengan kemampuan diri untuk menjadi tertib sesuai dengan konstruksi sosial dan hukum yang ada, dan juga kemampuan diri untuk taat, patuh dan berkomitmen untuk sesuai dengan apa yang dipandang baik oleh masyarakat. Oleh sebab itu orang yang memiliki disiplin akan cenderung memelihara ketertiban, misalnya siswa yang disiplin akan terlihat dari usahanya untuk cenderung menciptakan ruangan kelas yang tertib. Disiplin merupakan sebuah proses internalisasi nilai pada diri individu, yang dilakukan secara sadar untuk taat pada aturan yang berlaku.

Lalu, kenapa suatu ruangan kelas bisa mengalami tidak tertib dan disiplin? Berkaitan dua hal yakni guru dan siswa; dalam hal ini berkaitan dengan cara guru mensosialisasikan ketaatan (nilai yang penting) dan komitmennya terhadap rencana dan tujuannya. Ketidaktertiban itu bisa muncul dari kegagalan memainkan peran guru, memahami konsep disiplin dan ketiadaan dukungan kelembagaan. Sementara pada sisi mahasiswa, terjadi karena persiapan peran yang tidak memadai dan tarikan kelompok rujukan, sehingga terdapat tarik menarik antara nilai yang diajarkan dengan yang tidak diajarkan. Ketidaktertiban ini tercipta karena adanya perbenturan antara kebutuhan subkultur 
Dwi Sulistyawati, Imam Santosa, \& Deddy Wahyudi

Desain furnitur hasil kajian seting fisik kelas studio berbasis perilaku mahasiswa milenial

siswa dengan nilai budaya ideal dalam masyarakat. Misalnya "anak gaul itu identik dengan dugem" memunculkan perilaku bebas dan kehidupan postmodern. Bagi siswa generasi milenial yang sudah banyak dipengaruhi oleh teknologi informasi dapat membentuk perilaku budaya merunduk (Yuswohady, 2016) yang juga dapat mempengaruhi tingkat kedisiplinan mereka dalam hal waktu untuk berinteraksi dalam ruang kelas bersama.

Konsep Desain Kelas. Konsep Desain yang diterapkan dalam ruang kelas bidang seni dan desain adalah dengan menggunakan konsep kelas Studio, di mana aktivitas dan perilaku dalam proses belajarmengajar ditunjang dengan fasilitas-fasilitas dan atribut yang dapat mendukung proses perkuliahan tersebut berlangsung dengan menyesuaikan rata-rata jumlah rasio mahasiswa dengan dosen pendampingnya maximum 1:10. Konfigurasi meja dan kursi juga diatur sesuai dengan kelompoknya masing-masing. Sedangkan bentuk dan ukuran meja disesuaikan dengan kebutuhan aktivitas belajar pengguna dalam kelas studio. Konsep elemen desain interior juga mendukung fungsi dari kelas pada mata kuliah seni dan desain sebagai berikut: (1) unsur lantai menggunakan material yang dapat meredam suara dan memberikan kesan tenang dan nyaman; (2) unsur dinding dapat memberikan penunjang aktivitas dalam hal penggunaan material yang dapat meredam suara, penempatan pengaturan penghawaan alami, pencahayaan alami, dan sebagai media presentasi seperti fleksibilitas layar proyektor dan white board; (3) unsur plafon dapat memberikan penunjang dalam hal fleksibilitas pencahayaan buatan, penempatan proyektor; dan (4) unsur furnitur meja dan kursi yang dapat mendukung fleksibilitas beraktivitas di dalam menjalankan program belajar pada mata kuliah Perancangan Interior baik aktivitas utama maupun penunjangnya.

\section{Kesimpulan}

Dari hasil yang diperoleh melalui analisis programing maka fasilitas yang dibutuhkan dalam proses belajar-mengajar pada ruang kelas studio tidak dapat dibuat dengan cara klasikal lagi seperti yang sudah dan sedang berjalan. Bentuk, konfigurasi dan ukuran meja harus dapat menunjang aktivitas dan perilaku proses belajar-mengajar pengguna (dalam hal ini mahasiswa, dosen utama dan dosen pendamping). Jumlah besaran ruang dengan jumlah pengguna harus disesuaikan. Fasilitas penunjang
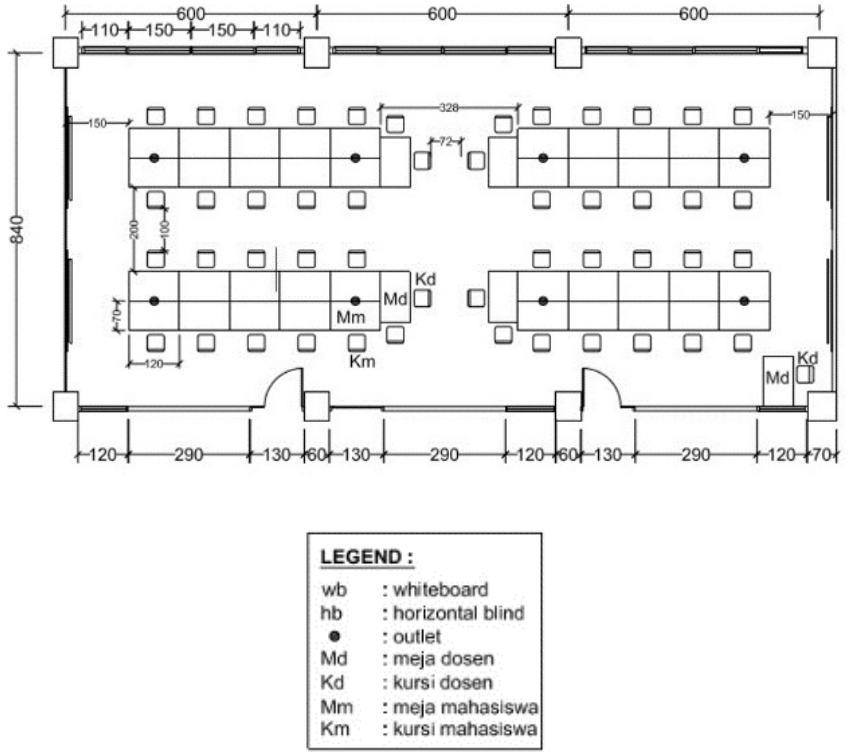

Gambar 3. Layout plan kelas studio

seperti tempat sampah, outlet, projector dan layar, harus dapat tersedia. Sedangkan tata udara, tata suara dan tata cahaya perlu diatur dan disesuaikan dengan keadaan kelas yang sedang berlangsung.

Berdasarkan konsep desain dari proses analisis programing maka dapat diperoleh Model Seting Fisik untuk kelas pada bidang Seni dan Desain (Gambar 3), yaitu dengan pertimbangan: Kelas Studio; Sistem gruping/kelompok; Rasio (perbandingan mahasiswa-Dosen 1:10); Spasial gerak dan sirkulasi (ukuran ruang terhadap kapasitas pengguna); Kebutuhan fasilitas terhadap aktivitas berperilaku pengguna ruang (mahasiswa, dosen pembimbing, dan dosen utama); Furnishing yang fleksibel, Meja dapat difungsikan sebagai tempat yang utama yaitu untuk menulis dan menggambar (bisa dimiringkan) dan sebagai unsur penunjang yaitu ada rak untuk menyimpan tas dan peralatan, sedangkan kursi dapat bergeser dengan mudah (roda); Fasilitas Penunjang belajar-mengajar (projector dan layar, outlet, microphone dan loudspeaker, glass board ); dan Elemen Desain Interior (lantai: karpet loop pile, plafon dengan titik lampu disesuaikan, dinding berfungsi sebagai peredam dengan sebagian partisi yang kedap suara.

Agar mendapatkan hubungan guru-siswa di ruang kelas sebagai sebuah interaksi sosial, di mana konsep persahabatan dan pemuridan terjadi dalam hubungan yang timbal balik, terjalin suatu kontak dan komunikasi yang bersifat teratur dan terstruktur, dan juga merupakan sebuah sistem pertukaran, dalam rangka memperoleh keuntungan, baik yang 
bersifat ekstrinsik berupa materi dan kebendaan, maupun intristik berupa nilai (peringkat), penghargaan, pengakuan, empati dari para murid, dan unsur lainnya maka dibuatlah seting fisik dengan konfigurasi furnitur dengan sistem berkelompok.

Seting fisik dengan konfigurasi sistem berkelompok dimaksudkan agar perilaku dominatif tidak terjadi akibat dengan posisi dosen sebagai sumber kebenaran, yang seperti dipandang maha tahu, tokoh penentu benar salah, dalam hal ini siswa dianggap sebagai mahluk yang senantiasa harus dibimbing dan diarahkan oleh dosen.

Seting fisik kelas studio tersebut adalah untuk mengatasi perilaku kepemimpinan dosen yang dapat mempengaruhi produktivitas mahasiswa di ruang kelas, yang dibedakan menjadi autokratik, demokratik, dan laisser-faire. Autokratik adalah kepemimpinan otoriter yang tidak memberikan ruang bertukar pendapat atau pandangan antara guru-murid. Demokratik adalah adanya ruang untuk bertukar pandangan atau pendapat dan kebaikan bersama dikonstruksikan secara bersama melalui musyawarah. Sedangkan laisser-faire adalah kepemimpinan yang cuek, yang memperbolehkan peserta didik melakukan apa saja apabila dipandang penting untuk dilakukan). Perilaku demokratis bagi mahasiswa milenial diharapkan merupakan perilaku yang dapat memberikan ruang gerak bagi kreativitas bersama yang membentuk sosial-budaya yang solider dan saling menghargai.

Permodelan seting fisik kelas yang dihasilkan penulis diasumsikan dapat mendukung pembelajaran pada matakuliah seni dan desain bagi mahasiswa Milenial yang memerlukan pengembangan atas karakter Creative, Confidencce, dan Connected serta mengakomodir proses belajar mengajar yang berpusat pada dosen/teacher centered atau berpusat pada siswa learner centered.

Rekomendasi lain berkaitan dengan permodelan ini adalah furnitur berupa meja sebagai penunjang aktivitas belajar (Gambar 4). Produk berupa meja dibuat fleksibel dengan mengikuti standarisasi ergonomi dan antropometri meja yang sudah ada, tetapi dimodifikasi dengan mengakomodir kepentingan proses pembelajaran pada mata kuliah seni dan desain dalam mengerjakan tugas: (1) aktivitas mengerjakan tugas secara manual yang rata-

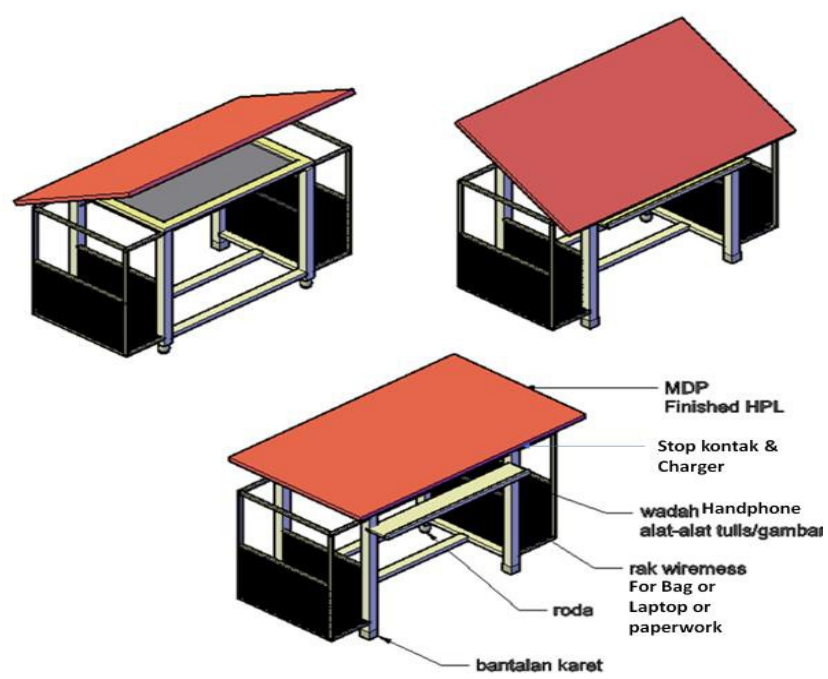

Gambar.4. Meja mahasiswa

rata dengan media kertas gambar dan penunjang alat tulis dan gambar; dan (2) aktivitas mengerjakan tugas dan mencari referensi menggunakan laptop dan penunjang wifi dan outlet (stop kontak \& charger).

\section{Daftar pustaka}

Ali, H., \& Purwandi, L. (2017). The Urban Middlle-Class Millennials Indonesia: Financial and Online Behavior. Retrieved June 6, 2020, from http://alvara-strategic.com/wpcontent/uploads/whitepaper/The-Urban-Middle-ClassMillenials.pdf

Azwar, S. (2007). Sikap Manusia: Teori dan Pengukurannya (2nd ed.). Yogyakarta: Pustaka Pelajar.

Creswell, J. W. (2014). Research Design: Qualitative, Quantitative, and Mixed Methods Approaches (4th ed.). California: SAGE Publications, Inc. https://doi.org/10.1007/s13398-014-0173-7.2

Damsar. (2011). Pengantar Sosiologi Pendidikan. Jakarta: Kencana.

Lovitt, T. C. (1984). Tactics for Teaching. Ohio: C.E. Merrill Pub. Co.

Murray, H. G. (1985). Classroom teaching behaviors related to college teaching effectiveness. New Directions for Teaching and Learning, 1985(23), 21-34. https://doi.org/10.1002/tl.37219852305

Strauss, W., \& Howe, N. (2000). Millennials rising: The next great generation. New York: Vintage Books. 